\title{
An Approach to the Construction of Green Infrastructure and Green Spatial Governance for a City
}

\author{
Ho-Mo Hung \\ Department of Urban Planning and Development, Chinese Culture University, Taipei 111, Taiwan
}

\begin{abstract}
There is a substantial significance to construct city green spaces for improvement of the city environment and ecological function. The conservation of city green space includes a sound plan of green space and the non-statutory parks and green open space, which are open spaces of both public and private land to be greened, they both become the basis for constructing an ecological green network of great city environment. To manipulate cross-sectoral integration, the city greening practice performs effective implementation. The main objective of an approach is to perform the governance indices of green spaces by expert questionnaire and then draft the greening strategies for Taipei city to improve the green landscape and the quality of city environment. The research draws on the green infrastructure and green ecological network system, analyzes the green ecological resources and the characteristic and structure of city spaces in Taipei city, in the meanwhile, learns the domestic and international experiences of greening development. By means of city green space of activation transformation and program of action under greening performance, Taipei city promotes the green image and the quality of city environment and green city landscape.
\end{abstract}

Key word: Green spatial governance, city greening, green ecological network, green spatial governance index.

\section{Introduction}

Under the condition of the economic growth and the increase in population, cities follow the problems of the environment pollution. Due to excessive development and the short of system planning, many buildings and roads occupy the city land, and the damaged city nature as well as the depletion of ecological benefit break down the city landscape and the quality of living environment. It makes the city residents hope to return to the embrace of the nature.

Including the city parks and the natural green areas, those natural green spaces link together to increase the connection of the city landscape, provide habitats for the wildlife in city and get intact structure and function of the city ecosystem gradually. Therefore, the green spaces play an important role in the process of the city development. Those are the positive spaces in city. Besides the beautifying and greening functions for the city environment, there are the substantial

Corresponding author: Ho-Mo Hung, Ph.D., main research field: landscape planning and design. functions of the construction of the whole city ecosystem and the creation of the city features and image.

Because of narrow area and many people, the rapid development of industry and commerce, urbanization, and every inch of land were occupied with the buildings and roads in Taiwan. The Taiwan cities became dull as desert and bush, the ecological functions of the nature environment were reduced, and the city landscape and environment quality were degraded little by little. This research area is Taipei city which is the northern part of Taiwan. The Taipei city is superior development at a high level. The cultural thought is matured gradually, and make more convenient by the facilities and structures, but the ecological environments are ruined and damaged. Therefore, in order to improve the imbalance development of city, there must wake up the ecocity consciousness of residents, convert the green landscape image of residents, rally the social culture landscape in city, and create the modern city provided with ecological functions and ecological beautification. 
The main objective of an approach is to perform the governance indices of green spaces by expert questionnaire and then draft the greening strategies for Taipei city to improve the green landscape and the quality of city environment. The research draws on the green infrastructure and green ecological network system, analyzes the green ecological resources and the characteristic and structure of city spaces in Taipei city, discusses green policies and regulation, in the meanwhile, learns the domestic and international experiences of greening development. By means of city green space of activation transformation and program of action under greening performance, Taipei city promotes the green image, the quality of city environment and green city landscape.

\section{The Relative Research and Concepts}

\subsection{The Concepts of Connection Design of the Green Infrastructure}

Green infrastructure or blue-green infrastructure is a network providing the ingredients for solving urban and climatic challenges by building with nature [1]. Green infrastructure uses vegetation, soils and natural processes to manage water and create healthier urban environments [2]. At the scale of a city or county, green infrastructure refers to the patchwork of natural areas that provides habitat, flood protection, cleaner air and cleaner water [3]. At the scale of a neighborhood or site, green infrastructure refers to stormwater management systems that mimic nature by soaking up and storing water. These neighborhood or site-scale green infrastructure approaches are often referred to as low impact development [4]. Green infrastructure can be a centerpiece of smart regional and metropolitan planning, ensuring that communities have a livable environment, with clean air and water, for generations. Green infrastructure can be designed to address the needs of wildlife, which are increasingly threatened by climate change, providing systems of corridors or greenways to enable movement through human settlements. Those corridors are often beautiful places that people want to live near too $[5,6]$.

For promoting environment quality and city landscape and leaping forward the path of international city, there are many greening programs and green plans to green and beautify the city environment by ecological design and reconstruct "the lost space" and green landscape in city [7]. The city greening is the main job of city development and construction. A focal point is to increase more green cover areas whose functions improve the city environment, resolve the environment problems and keep the ecosystem balance. There are different environmental and ecological conditions in the different environments to influence the scale of the green cover area [3, 8]. As for parks, the land scale and area to demand for leisure and recreation influence the scale of the green cover area. The green nodes, the patches and matrix of the corridors interweave to form the ecological network system of city landscape $[9,10]$. Whole open space system is provided with the comprehensive environmental effects for the city, such as maintaining species and ecological process, sustainable hydrological process, improving climate, social economy and the formation of regional characteristic. Through the processes of ecological design and planning, dynamic ecological management and practice, it is able to achieve the beautiful and green modern city, constructing the city landscape and image [11, 12].

\subsection{The Green Spatial Governance Indices}

Good city governance must enable all the city people to access the benefits of city citizenship. UN-HABITAT is promoting the following definition of good city governance, which is inextricably linked to the welfare of the citizenry. Through good city governance, citizens are provided with the platform which will allow them to use their talents to the full to improve their social and economic conditions $[13,14]$. Through UN-HABITAT's and other partners' operational activities, the campaign proposes that good 
city governance is characterized by sustainability, subsidiarity, equity, efficiency, transparency and accountability, civic engagement and citizenship, and security, these norms are interdependent and mutually reinforcing [15].

As a logic of city governance model, the green spatial governance is used to improve the quality of city environment and benefits of city residents. The green spatial governance includes the development stages, transformation, drive-change force of city parks and green lands, city greening skills and knowledge interweave the flexible civic participation, good green lands planning and management [16]. Dependent on the Taipei Future 30 years City Development Vision Master Plan, the future visions of Taipei city to be an ecocity that have 6 themes: tree, aqua, infrastructure, people, energy and intelligent [17]. This research linked up UN-HABITAT's good city governance indices with 6 themes to establish 5 dimensions of green spatial governance those are creativity, accountability, diversification, civic participation and citizenship, and security [15, 17].

\section{The Status of Greening Development in Taipei City}

Taipei city, situated in Taipei basin in the northern part of Taiwan island, stretches 18 kilometers from east to west and 27 kilometers from south to north. The city covers a total area of 27,179.97 hectares and is surrounded by the Taipei county. Mountains and hills that rise steeply eastward on the north, east and south surround the city. Major mountains range from north to south including Dadu, Chixing, Wuzhi, Tuku and Erger, which account for over one-half of the total city area, providing the majority of green land and water conservation resources for the city. Other water resources of the city also come from the convergence of the Danshui river, Jilong river and Jingmei creek. The Taipei city is graceful.

At the end of May 2015, the demographic statistics show that the city have 2,705,949 residents. The population density of the Taipei city is 9,956 persons per $\mathrm{km}^{2}$. The land use of Taipei city is identical to that of the jurisdiction area of the city, the city planning area (46.28\%) are designated for city development, and the non-city land (53.72\%). By the end of Jan. 2015, this city has built 569 parks covering an area of 8.00 million squares meters, 205 green lands covering an area of 0.68 million square meters. On the average, each citizen could enjoy 51.6 square meters of parks and green lands. Besides, this city had 116,050 trees along the streets and 1,101,224 trees for other purposes. On the average, every two citizens have a tree [18].

The achievements of city greening promote the quality of city environment and the health and life for residents. Moreover, that is one brand to promote the international level. Taipei city is the capital area, due to centralized population, environment pollution problems, and inappropriate development in which there was the city order, functions and environment quality degraded little by little.

\section{The City Greening Development and Improvement in Taipei}

In order to create sustainable city ecosystems and green ecocity, Taipei city government makes goals, governance policies, and implementation procedures to deal with the complex and severe problems: physical, biological, and sociocultural elements of city landscape. Considering the environment resources, base on the principles of ecological design, regarding the ecocity as the goal, the Taipei city constructs more green spaces, which connect each other to be the ecological green network system. Not only the city environment quality but also green landscape of Taipei city can be promoted soon, which reinforces its potential to internationalize and creates the glamorous, diversifying, livable and green Taipei city.

\subsection{The Strategies of Green Spatial Governance in Taipei}

Using the expert questionnaire, this research 
applied the Delphi and Analytic Hierarchy Process (AHP) in the establishment of 5 dimensions of green spatial governance which are creativity, accountability, diversification, civic participation and citizenship, and security, for the 15 indices of green spatial governance to the operation of city greening in Taipei city.

Through the 5 dimensions of green spatial governance, the strategies of green spatial governance were established.

(1) The aspects of policy and ordinance: the good green spatial governance in Taipei was set up the policies and ordinances of city parks and green lands, counseling economic incentives, forwarding cooperation and mutual benefit between public and private sectors.

(2) The aspects of rational planning and management: training the landscape professionals and cultivating of landscape talents, they practice in landscape planning and design, who will consider the conditions of the physical environment and the public demands, to make the park green spaces which exhibit the characteristics and vitality and habitability of Taipei city. These characteristics and good quality increase the public's identity and belonging sense in Taipei city.

(3) The concepts of conservation and ecological design: the benefits of city greening development are absorbing and sequestering atmospheric carbon dioxide $\left(\mathrm{CO}_{2}\right)$, filtering air and water pollutants, stabilizing soil to prevent or reduce erosion, providing wildlife habitat, decreasing solar heat gain, lowering the public cost of stormwater management infrastructure and providing flood control. Moreover, city environment reduces energy usage through passive heating and cooling, providing wildlife habitat, and creating ecological balance between built and natural environments. The good ecological design of city green landscape can combat with climate change, create healthy built environments, and improve quality of life $[5,8,19]$.

(4) The aspects of civic participation and cognition: to promote public awareness and values of nature and ecosystem, the city government rewards and encourages participation or maintenance of the quality of environmental parkland, and makes partnership with the public to co-manage the urban landscape, for making the eco-green Taipei.

(5) The aspects of security and health: to promote parks and green spaces as places to improve health and well-being, prevent disease through physical activity, play, relaxation, and contemplation for people.

\subsection{The Schemes of the City Greening for Improvement}

The greening for modification of city environment is pointed out to establish and maintain the healthy and safe green living environment, developing the effects of nature conservation, maintenance environment and human physical and psychological health care $[20,21]$. The propositions of the greening are:

(1) For furthering the environment functions, increasing the green area for each resident and enjoying the idyllic life, Taipei city should keep the large-scale green spaces, construct the city forest and increase city green cover area in number. Therefore, in Taipei city, there will be city feature, special symbol, plentiful civil life and beautiful green city environment. The principles of construction and even distribution of Taipei green spaces are proposed:

a: There is one park for one kilometer in each administration division as a goal, especially the center districts of superior development, such as Taann district, Datong district and Wanhua district which need more green spaces;

b: To reserve the existed trees in park and increase the green cover area, it promotes the quality of parks and improves the city landscape and naturalness of the park and green land;

c: It is important that the decision makers and planners should improve their profession and knowledge about ecology, environics and the values 
of using natural resources;

d: In the city's land use plan, the different parks should distribute evenly and park and green land area should be increased. The non-built lands, such as low wetland, disuse land, sloping field and river waterfront are planned and beautified with the ecological design method to increase the recreation settings. For instance, Kendu area is wetland which was planned to be the watch-bird nature park;

e: The trees getting with the natural conditions are chosen. They provide for city environment with the ecological functions and improve the city living environment;

$\mathrm{f}$ : For the different objectives and residents, the park and green land should be planned and designed properly, which further recreation pleasure, provide activity settings and accomplish the mission.

(2) It should construct the garden and the vertical green wall to beautify and green the industry, commerce and residential district. The greening development is started with the points, lines, plane and upward the vertical planting.

The points are home gardens and parks. The home garden that is the front land of the building can plant the trees and flowers to improve the living space. The home garden is the symbol of high quality residential district, which is the outdoor living room, and the house extension. The lines are streets and roads greening. The planes are the park and green land system.

The vertical greening is to put the potted flowers on the windowsill and balcony, and construct the roof-garden on the roof. To construct the roof-garden, it need not only eliminate the buildings constructed without licence and waste stacked, but also produce the comfortable environment, furthering the physical and psychological health and life pleasure for citizen. That can maintain the city landscape and improve the residential environment quality.

(3) The street and road design should be plant more road trees to make the boulevards. The space under the viaduct plants trees and shade-resisting herbaceous plantings and disposes the bike-way.

(4) The river corridors and the ring-road expressway connect with the mountain districts and the blue and green open spaces to form the ecological green and waterfront bluebelt network system. For instance, Danshui river connects the Taipei districts with Panchiao city and Sanchung city of Taipei county, Jingmei creek in Mucha connects the Wenshan district of Taipei with Hsintien city of Taipei county.

(5) The network of greening development mediation: the river corridors and the ring-road expressway connect with the mountain districts and the watershed open spaces. The planes of the park and green area form the ecological green network system and waterfront bluebelt network system [20, 22].

\section{Conclusion}

As for city, the influencing factors are more complex, such as police and ordinance, the substantial characteristic of physical environment, city ecosystem and nature process, plant characteristic and function, city space structure, land use pattern, the distribution and quantity of green space, population quality, the problem of environment pollution and the demand for leisure and recreation. From thinking systematically and wholly, the achievements of ecological design are making the balance relationships between human and nature, social economic development and resources, organism and non-living organism and ecosystems.

The beauty and tidiness of a city has something to do not only with the health of city residents but with its image of city landscape. The greening development is the important thing to improve the city landscape and environment quality, with the aim to provide residents with natural, lively, and harmonious living environments. To adopt rational policy of development that protects sensitive areas of the environment. That is the sustainable Taipei city toward “a green ecocity”. 


\section{References}

[1] Benedict, M. A., and Edward T. M. 2002. "Green Infrastructure: Smart Conservation for the 21st Century." Renewable Resources Journal 20 (3): 12-17.

[2] Fábos, J. G. 2004. "Greenway Planning in the United States: Its Origins and Recent Case Studies.” Landscape and Urban Planning 68: 321-342.

[3] Cook, E. A. 1991. "City Landscape Networks and Ecological Planning Framework.” Landsc. Res. 16: 7-15.

[4] EPA. 2012. "Addressing Green Infrastructure Design Challenges in the Pittsburgh Region.” In Green Infrastructure Technical Assistance Program, 9-12.

[5] American Society of Landscape Architecture. 2012. "Professional Practice-Green Infrastructure." Accessed June 15, 2015. http://www.asla.org/greeninfrastructure.aspx.

[6] Cook, E. A., and Van, Lier, H. N. 1994. Landscape Planning and Ecological Networks. Amsterdam: Elsevier.

[7] Memarian, Alireza, and Navid, Niazkar. 2014. "The Lost Space of Architecture in the Context of Urban Lost Space.” International Journal of Engineering and Advanced Technology (IJEAT) 3 (5): 311-321.

[8] Wickham, James, D., Riitters, Kurt, H. B., Wade, Timothy G., and Vogt, Peter. 2010. “A National Assessment of Green Infrastructure and Change for the Conterminous United States Using Morphological Image Processing." Landscape and Urban Planning 94: 186-195.

[9] Forman, W. E., Olson, J. D., and Forman, T. T. 1996. Landscape Ecology Principles in Landscape Architecture and Land-Use Planning. Washing DC: Island Publishers.

[10] Hough, M. 1984. City Form and Nature Process. London: Croom Helm.

[11] Little, C. E. 1990. Greenways for America. London: The Johns Hopkins Press Ltd..

[12] Schrijnen, P. M. 2000. "Infrastructure Networks and Red-Green Patterns in City Regions.” Landscape and Urban Planning 48: 191-204.

[13] Bueren, Ellen, Van. 2009. Greening Governance: An
Evolutionary Approach to Policy Making for a Sustainable Built Environment. The Netherlands: IOS Press under the Imprint Delft University Press.

[14] Pierre, J. 1999. "Models of City Governance: The Institutional Dimension of City Politics.” City Affairs Review 34 (3): 372-96.

[15] Seboka, Berhanu. 2003. "Module I. A. City/Municipal Management Strategy.” In 5th Urban and City Management Course for Africa, 1-28.

[16] Bueren, Ellen Van. 2009. Greening Governance: An Evolutionary Approach to Policy Making for a Sustainable Built Environment. The Netherlands: IOS Press under the Imprint Delft University Press.

[17] Taipei City Government. 2010. “Taipei Yearbook 2010.” Accessed June 15, 2015. http://yearbook.taipei/ct.asp?xItem $=5965183 \& c t$ Node $=45$ $805 \& \mathrm{mp}=100089$.

[18] The Parks and Street Lights Office. 2015. "The Types of the Parks and Greenlands in Taipei City.” Accessed May 19 ,

2015. http://pkl.taipei.gov.tw/ct.asp?xItem=156239\&CtNode $=4$ 6936\&mp=106011.

[19] Erickson, Donna, L. 2004. "The Relationship of Historic City Form and Contemporary Greenway Implementation: A Comparison of Milwaukee, Wisconsin, USA and Ottawa, Ontario (Canada)." Landscape and Urban Planning 68: 199-221.

[20] Sharma, Archana. 2010. "Rethinking Greenways Design in Context of Sustainable Development: Towards Landscape Synergism, Architecture Publications and Other Works.” Accessed August 12, 2015. http://trace.tennessee.edu/utk_architecpubs/13.

[21] Spretnak, C., and Capra, F. 1984. Green Politics: The Global Promise. New York: E. P. Dutton Inc..

[22] Jaarsma, C. F. "Ecological 'Black Spots' within the Ecological Network: An Improved Design for Rural Road Network Amelioration.” In Ecological Networks and Greenways: Concept, Design, Implementation, edited by Jongman Rob, H. G., and Gloria, Pungetti. UK: Cambridge University Press. 